\title{
Screening Ornamental Sunflowers in the Seedling Stage for Flowering Reaction to Photoperiod
}

\author{
Hans C. Wien ${ }^{1}$
}

AdDitionAl INDEX wORDs. anthesis, cut flower, flower initiation, Helianthus annuus

SuMMARY. Ornamental sunflower (Helianthus annuus) cultivars grown as cut flowers range in sensitivity to photoperiod with regard to flowering from facultative short day (SD) to facultative long day (LD), with others insensitive to daylength. SD sensitivity is a problem for production in tropical areas, or in early spring sowings when the daylength triggers early flowering, and leads to small flowers and production of unsightly axillary buds. In the current work, 59 cultivars of sunflower were exposed to either 12- or 16-hour photoperiod in seedling trays in a greenhouse for 3 weeks, and transplanted outside. At flowering, plant height, leaf number, and flower diameter were measured. The studies were conducted in 2006, 2007, 2009, 2011 , and 2012 with two cultivars (Procut Lemon and Sunrich Orange) serving as controls in each trial. Of the 59 cultivars screened, $52 \%$ were found to be dayneutral, $44 \%$ were SD, and two $(3 \%)$ had a LD reaction. Two standard cultivars grown in each season showed consistent reactions to the photoperiod treatments in each year. The seedling screen is useful to identify cultivars suited for production in early spring in a temperate environment.

$\mathrm{S}$ unflower has become a popular cut flower in North America, where it has been grown primarily in the field during the summer season (Armitage and Laushman, 2003). As demand has increased for sunflower at other times of the year, the daylength response for flowering of the cultivars has become important. Over the years, many sunflower cultivars have been classified as facultative SD plants (Dyer et al., 1959; Hayata and Imaizumi, 2000; Yanez et al., 2005), but daylength-neutral and even facultative LD cultivars have also been identified (Goyne and Schneiter, 1988; Mattson and Erwin, 2005; Schuster and Boyce, 1971). If SD cultivars are grown under SD conditions, they flower early, are small in stature, and have small flowers. These cultivars only develop their "normal" height and flower size characteristics in the longer days of summer that make them suitable for use as cut flowers at that time. As new cultivars are continually introduced by seed companies for the cut flower trade, it is important

Professor, Department of Horticulture, Cornell University, Ithaca, NY 14853

We gratefully acknowledge support from the Association of the Specialty Cut Flower Growers Research Foundation and federal Hatch project funds.

The author thanks Francoise Vermeylen for expert help on statistical analysis.

${ }^{1}$ Corresponding author. E-mail: hcw2@cornell.edu. to test the daylength reaction of these new lines, so that growers will be aware of the time of year to which production of these lines may be restricted.

Fortunately, the task of daylength screening of sunflower has been made easier by the finding that for many sunflower cultivars, flower primordia are formed within 3 weeks after emergence (Marc and Palmer, 1981; Yanez et al., 2012). If sunflower cultivars are sensitive to daylength before flower initiation, it allows a daylength screening process to be imposed during the seedling stage, and the resulting effects to be observed under field conditions thereafter, as was reported by Blacquière et al. (2002). We used this methodology to expose seedlings of 59 sunflower cultivars developed for use as cut flowers to long or short photoperiods in experiments over 5 years, and classified their responses. The objectives of the current work were to test cut-flower cultivars of sunflower for the effect of daylength in the seedling stage on flowering date, number of leaves, plant height, and flower diameter.

\section{Materials and methods}

The findings of Blacquière et al. (2002) suggest that sunflower can be screened for flowering response to daylength by imposing photoperiod treatments in the seedling stage. Accordingly, seeds of sunflower cultivars were sown in 72-cell seedling trays having individual cell volumes of $56 \mathrm{~mL}$ and containing a peat-vermiculite artificial soil mix, and placed on greenhouse benches equipped with automatic blackout curtains that provided $12 \mathrm{~h}$ of photosynthetic light consisting of daylight supplemented by metal halide lamps supplied from 0700 to $1900 \mathrm{HR}$. Greenhouse temperatures were maintained at $24 \pm$ $2{ }^{\circ} \mathrm{C}$. Half of each bench was screened from the SD portion and received an additional $4 \mathrm{~h}$ of photoperiodic lighting supplied by screw-in fluorescent fixtures that provided $5 \mu \mathrm{mol} \cdot \mathrm{m}^{-2} \cdot \mathrm{s}^{-1}$ photosynthetic photon flux at plant level supplied as a day extension from 1900 to $2300 \mathrm{HR}$. The seedlings thus received either a $12-\mathrm{h}(\mathrm{SD})$ or a $16-\mathrm{h}$ (LD) daylength treatment for the first 3 weeks after emergence. To prevent excessive elongation of the seedlings in the trays, they were brushed once daily by passing a wooden stick manually over the trays for about a minute duration, starting when the seedlings were about 1 week old. Space restrictions on the daylength greenhouse bench allowed only one replication on the bench at one time in the first 3 years, so replications in 1 year were sown consecutively at 3 -week intervals. In 2011 and 2012, both replications were grown and screened at the same time. During the seedling growth period, the trays were fertilized with a $15 \mathrm{~N}-2.2 \mathrm{P}-12.5 \mathrm{~K}$ nutrient solution at the rate of $15 \mathrm{mg} \cdot \mathrm{L}^{-1}$ nitrogen during weekdays, and plain water on weekends.

Seedlings were transplanted to an outdoor experimental area near

\begin{tabular}{llll}
\hline $\begin{array}{l}\text { Units } \\
\text { To convert U.S. to SI, } \\
\text { multiply by }\end{array}$ & U.S. unit & SI unit & $\begin{array}{l}\text { To convert SI to U.S., } \\
\text { multiply by }\end{array}$ \\
\hline 29.5735 & $\mathrm{fl} \mathrm{oz}$ & $\mathrm{mL}$ & 0.0338 \\
2.54 & inch $(\mathrm{es})$ & $\mathrm{cm}$ & 0.3937 \\
1 & $\mathrm{ppm}$ & $\mathrm{mg} \cdot \mathrm{L}^{-1}$ & 1 \\
$\left({ }^{\circ} \mathrm{F}-32\right) \div 1.8$ & ${ }^{\circ} \mathrm{F}$ & ${ }^{\circ} \mathrm{C}$ & $\left({ }^{\circ} \mathrm{C} \times 1.8\right)+32$
\end{tabular}


Ithaca, NY (lat. $42.42^{\circ} \mathrm{N}$, long. $\left.76.50^{\circ} \mathrm{W}\right)$ having sandy loam soil (coarse-loamy, mixed, active, mesic Lamellic Hapludalf), on beds 4 inches high and 40 inches wide, watered by two trickle irrigation lines, and covered with black polyethylene mulch. Seedlings were spaced $9 \times 9$ inches apart in four rows on each bed. There were 24 seedlings per daylength treatment for each cultivar. Experimental design in the field was a split plot, with daylength treatment as main plot, and cultivars as subplots. This arrangement minimized shading by adjacent plots, as nearly half the cultivars had reduced height after SD treatment. The number of cultivars screened, the number of replications, and their dates of planting in each year are shown in Table 1. To quantify the variation in the screening conditions over the 5 years, the two cultivars, Procut Lemon and Sunrich Orange, were included in each planting. 'Procut Lemon' has consistently produced no reaction to the treatments imposed, whereas 'Sunrich Orange' flowered nearly 3 weeks earlier after SD treatment.

Plants were harvested at anthesis, defined as the time when the majority of petals (ray flowers) had unfolded to an angle of $90^{\circ}$ or more to the disk. At harvest, plant height was measured from the soil surface to the top of the flower head and flower disk diameter was taken as the distance across the disk ignoring petals. Leaf number included those on the main stem, leaf scars at the stem base, and leaves near the head that had visible petioles.

The effect of the seedling daylength treatments on the two standard cultivars was analyzed statistically via JMP software (version 11; SAS Institute, Cary, NC) using a mixed model, with year, cultivar, treatment, and cultivar $\times$ treatment as fixed effects. Statistical analysis of the daylength reaction of the 59 cultivars screened was done using a mixed model, with replications random, and fixed effects for cultivars, treatments, and their interactions. Each year was analyzed separately.

\section{Results}

Daylength treatments applied to sunflower seedlings for the first 3 weeks after emergence had profound effects on some cultivars (Table 2). The two cultivars that were included in each planting of the cultivar screen trials showed two such extremes. 'Sunrich Orange' flowered $18 \mathrm{~d}$ earlier when given 12 -h daylength compared with 16-h daylength, whereas 'Procut Lemon' showed no difference in time to flowering after the two treatments. The differences in time to flowering with daylength treatment for 'Sunrich Orange' were also

Table 1. Timetable and number of sunflower cultivars screened for daylength sensitivity, and number of replications planted in specific years. Cultivars total more than those listed in Table 3 because 'Procut Lemon' and 'Sunrich Orange' and a few others were grown in more than 1 year.

\begin{tabular}{lccl}
\hline Yr & Cultivars (no.) & Replications (no.) & \multicolumn{1}{c}{ Dates of sowing } \\
\hline 2006 & 22 & 3 & 11 May, 5 June, 6 July \\
2007 & 16 & 3 & 15 May, 5 June, 29 June \\
2009 & 11 & 2 & 14 May, 5 June \\
2011 & 13 & 2 & 24 June \\
2012 & 12 & 2 & 16 May \\
\hline
\end{tabular}

Table 2. The influence of a 3-week daylength treatment begun at emergence on daylength-controlled greenhouse benches on flowering date and plant characteristics at flowering of 'Procut Lemon' and 'Sunrich Orange' sunflower, grown over 5 years. Plants were transplanted to the field after daylength treatment.

\begin{tabular}{lccccc}
\hline Cultivar & $\begin{array}{c}\text { Daylength } \\
(\mathbf{h})\end{array}$ & $\begin{array}{c}\text { Time to } \\
\text { flowering }(\mathbf{d})^{\mathbf{z}}\end{array}$ & $\begin{array}{c}\text { Ht } \\
(\mathbf{c m})^{\mathbf{y}}\end{array}$ & $\begin{array}{c}\text { Flower } \\
\text { diam }(\mathbf{c m})\end{array}$ & $\begin{array}{c}\text { Main stem } \\
\text { leaves (no.) }\end{array}$ \\
\hline Procut Lemon & 12 & 65 & 108 & 6.1 & 17 \\
Procut Lemon & 16 & 65 & 106 & 6.5 & 18 \\
Sunrich Orange & 12 & 56 & 78 & 4.2 & 16 \\
Sunrich Orange & 16 & 74 & 133 & 8.0 & 24 \\
Year & & $\mathrm{NS}^{\mathrm{x}}$ & $\mathrm{NS}$ & $* *$ & $\mathrm{NS}$ \\
Cultivar & & & & $* * *$ \\
Treatment & & $\mathrm{NS}$ & $\mathrm{NS}$ & $\mathrm{NS}$ & $* * * *$ \\
Cultivar $\times$ treatment & & $* * *$ & $* * *$ & $* * *$ & $* * *$ \\
\hline
\end{tabular}

${ }^{2}$ Days after sowing.

${ }^{y} \mathrm{l} \mathrm{cm}=0.3937$ inch

'Analysis via JMP software (version 11; SAS Institute, Cary, NC) using a mixed model, with year, cultivar,

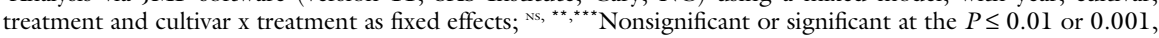
respectively.

reflected in other plant characteristics. The plants that flowered early were only $59 \%$ as tall, had significantly smaller flowers, and had 16 instead of 24 leaves (Table 2). In addition, the early flowering plants of 'Sunrich Orange' produced flower buds in the axles of nearly every leaf (Fig. 1), a disfiguring feature as these late buds did not reach anthesis until the main flower had senesced.

The statistical analysis of the two standard cultivars indicated that the effect of years was not significant for most variables measured (Table 2). This provided confidence that the daylength treatments were identifying the

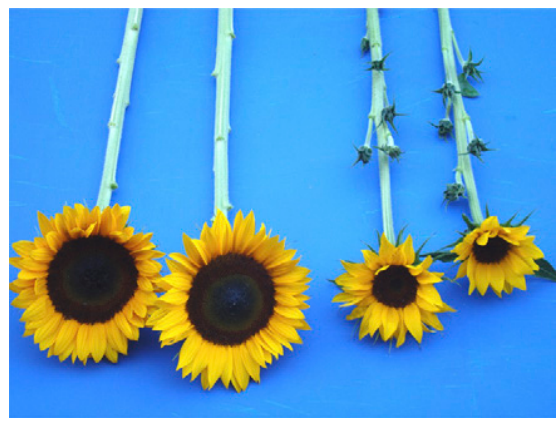

Fig. 1. 'Sunrich Orange' sunflower at anthesis, after being grown from emergence for 3 weeks under 16- (left) or 12-h daylength in a daylengthcontrolled greenhouse facility, before being planted to the field. 
Table 3. The reaction of 59 sunflower cultivars arranged in alphabetical order to exposure to either 12- or 16-h daylength in the first 3 weeks after emergence with regard to plant height at flowering and time to flowering after subsequent

transplanting to the field. Data are means of two or three replicated split plots each containing about 24 plants. Statistical analysis was conducted separately for each year, comparing cultivar by treatment slices.

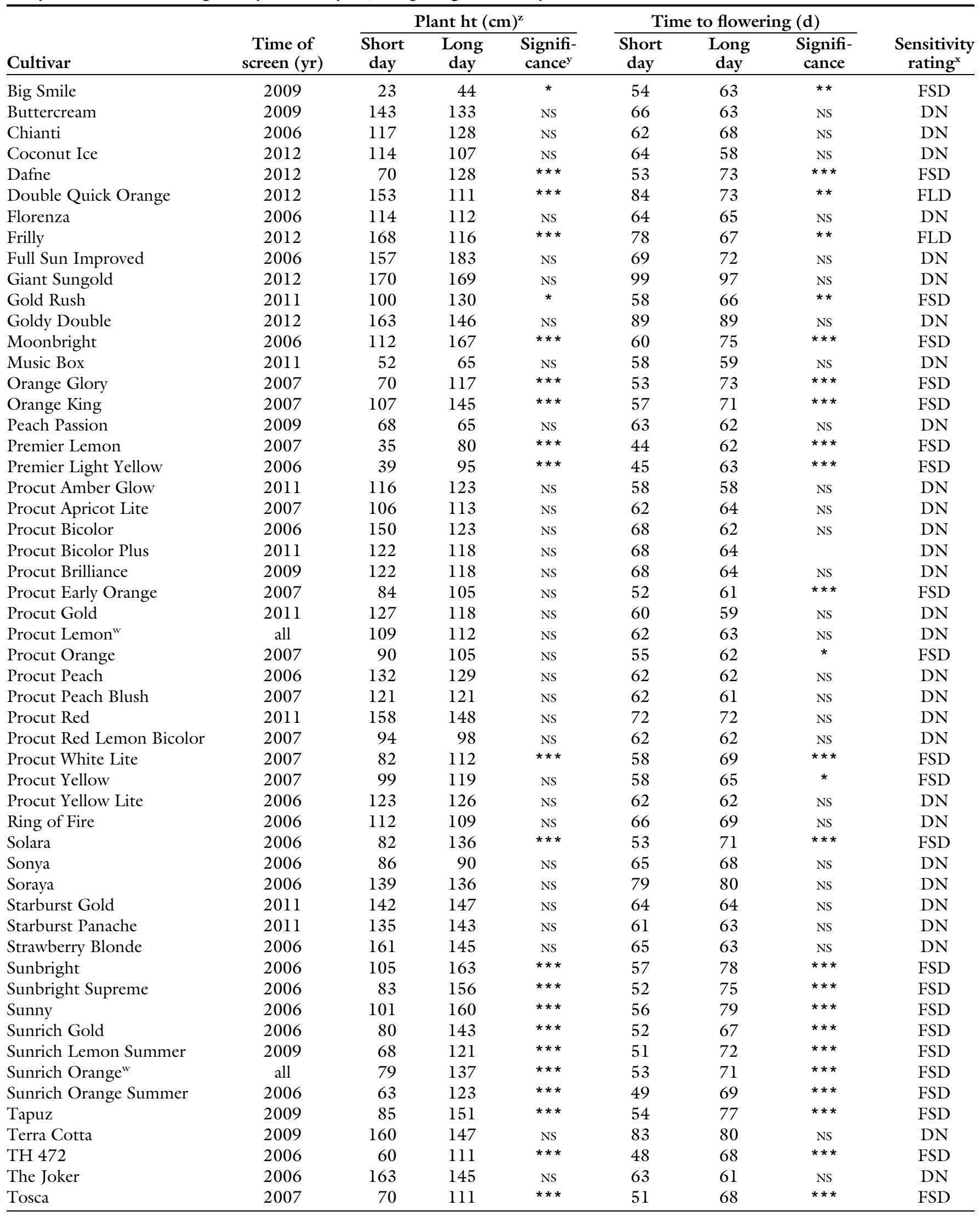

(Continued on next page) 
Table 3. (Continued) The reaction of 59 sunflower cultivars arranged in alphabetical order to exposure to either 12- or 16-h daylength in the first 3 weeks after emergence with regard to plant height at flowering and time to flowering after subsequent transplanting to the field. Data are means of two or three replicated split plots each containing about 24 plants. Statistical analysis was conducted separately for each year, comparing cultivar by treatment slices.

\begin{tabular}{|c|c|c|c|c|c|c|c|c|}
\hline \multirow[b]{2}{*}{ Cultivar } & \multirow[b]{2}{*}{$\begin{array}{c}\text { Time of } \\
\text { screen }(y r)\end{array}$} & \multicolumn{3}{|c|}{ Plant ht $(\mathrm{cm})^{\mathrm{z}}$} & \multicolumn{3}{|c|}{ Time to flowering (d) } & \multirow[b]{2}{*}{$\begin{array}{c}\text { Sensitivity } \\
\text { rating }^{x}\end{array}$} \\
\hline & & $\begin{array}{c}\begin{array}{c}\text { Short } \\
\text { day }\end{array} \\
\end{array}$ & $\begin{array}{c}\text { Long } \\
\text { day }\end{array}$ & $\begin{array}{l}\text { Signifi- } \\
\text { cance }^{y}\end{array}$ & $\begin{array}{c}\begin{array}{c}\text { Short } \\
\text { day }\end{array} \\
\end{array}$ & $\begin{array}{c}\text { Long } \\
\text { day }\end{array}$ & $\begin{array}{l}\text { Signifi- } \\
\text { cance }\end{array}$ & \\
\hline Valentine & 2006 & 104 & 113 & NS & 58 & 65 & NS & $\mathrm{DN}$ \\
\hline Vincent Choice & 2012 & 77 & 81 & NS & 47 & 56 & * & FSD \\
\hline Vincent Fresh & 2012 & 73 & 87 & NS & 47 & 54 & NS & $\mathrm{DN}$ \\
\hline Zahav & 2009 & 91 & 157 & $* * *$ & 55 & 77 & $* * *$ & FSD \\
\hline
\end{tabular}

${ }^{\mathrm{z}} 1 \mathrm{~cm}=0.3937$ inch.

yAnalysis via JMP software (version 11; SAS Institute, Cary, NC) using a mixed model, with replications random, and fixed effects for cultivars, treatments and their interactions; ${ }^{\mathrm{NS},}{ }^{*},{ }^{* *},{ }^{* * *}$ Nonsignificant or significant at the $P \leq 0.05,0.01$, or 0.001 , respectively.

${ }^{x}$ Classification of sunflower cultivars according to their reaction to photoperiod: day-neutral (DN); facultative short day (FSD), flowering significantly earlier after short-day than long-day treatment; facultative long day (FLD), flowering significantly earlier after long-day treatment.

wStandard cultivars grown each year. See Table 2 for detailed analysis.

showing no statistically significant difference between LD and SD treatments, and thus were considered daylength-neutral. Twenty-six cultivars $(44 \%)$ had a significantly longer delay (more than $7 \mathrm{~d}$ ) in flowering after LD vs. SD length treatments. Only 'Frilly' and 'Double Quick Orange' flowered $11 \mathrm{~d}$ earlier after LD treatment than SD treatment, and were considered to show a facultative LD response. This classification of sensitivity is rather arbitrary, as the difference between LD and SD treatments in flowering dates among cultivars ranged continuously from minus 11 to $23 \mathrm{~d}$ (Table 3, Fig. 2).

Earliness in flowering was accompanied by reduced plant stature (Table 3), smaller number of leaves, and other associated characteristics (not shown), such as increased axillary bud number and smaller flowers, as shown for 'Sunrich Orange' in Fig. I and Table 2.

\section{Discussion}

Our research confirms the findings of other investigators that sunflower cultivars exhibit a range of responses to daylength with regard to time to flowering, from facultative SD to facultative LD and daylengthneutral (Mattson and Erwin, 2005; Schuster and Boyce, 1971; Yanez et al., 2005).

By subjecting cultivars in the first 3 weeks after emergence to SDs or LDs, followed by growth to anthesis in LD conditions, the screening technique selected primarily for daylength effect on flower initiation, which can occur in the first 3 weeks from

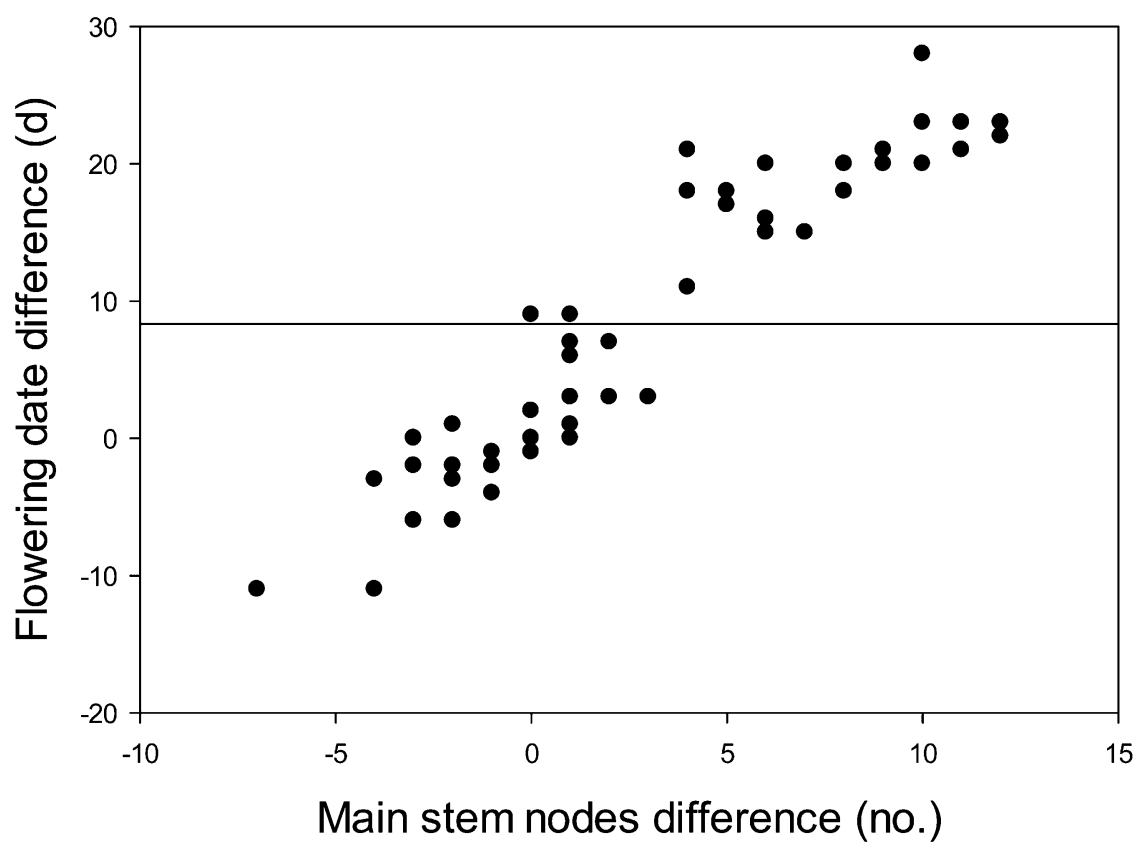

Fig. 2. The correlation between the difference in node number on the main stem and the flowering date difference for 51 sunflower cultivars when screened by exposing them in the seedling stage to either 12- or 16-h daylength. Leaf numbers were not determined for cultivars screened in 2011 , and are not included in the correlation. Line equation is $\mathrm{y}=2.01 \mathrm{x}+2.42, r=0.94$.

germination (Marc and Palmer, 1981; Yanez et al., 2012). Thus, exposure to an unfavorable photoperiod for flower initiation resulted in an increase in leaf number, as flower initiation was delayed (Table 2, Fig. 2). For the cultivars in this study, increasing the leaf number by one corresponded to a delay in flowering of about $2 \mathrm{~d}$ (Fig. 2).

For the extremely sensitive SD cultivars, the flowering delay was in some cases as long as the 2l-d LD treatment imposed, suggesting that flower initiation was prevented by LDs. But since in our trials, the seedlings were transplanted into the LD conditions of early to midsummer, we can conclude that flower initiation was only delayed, not prevented by the unfavorable photoperiod. Yanez et al. (2012) have shown similar results with 'Sunrich Orange' in greenhouse studies.

When the period from germination to anthesis is divided into time to flower initiation and the preanthesis flower development period, previous 
research has pointed out that response to daylength may differ in these two stages. Marc and Palmer (1981) found that two cultivars that showed little reaction to short daylength before flower initiation became SD sensitive between flower initiation and anthesis. Rawson and Hindmarsh (1982), on the other hand, found that five cultivars were hastened to initiate flowers by LDs, but the period to anthesis was shortened by SDs in three of these cultivars, making them appear day-neutral. Perhaps, more common was the response of 24 ornamental sunflower cultivars studied by Yanez et al. (2005), for which a SD response in time to visible flower buds was followed by additional SD reaction in the preanthesis period.

From a practical standpoint, the early screening test used here identifies cultivars that are accelerated to flower when exposed to SDs in the early seedling stage. These conditions occur if seedlings are produced under natural daylengths in March for transplanting to high tunnels. Although the early flowering noted for such plants is not in itself objectionable, the small flowers, short stem length, and profusion of axillary flower buds limit the commercial appeal of such plants (Fig. 1). An early LD treatment can eliminate these symptoms by keeping the plant in a vegetative stage during early development. Another solution is to choose daylength neutral cultivars for early production. As the technique used here only subjects the seedlings to the first 3 weeks of SDs, it may not be appropriate for cultivars that are to be grown under conditions of constant SDs.

\section{Literature cited}

Armitage, A.M. and J.M. Laushman. 2003. Specialty cut flowers. 2nd ed. Timber Press, Portland, OR.

Blacquière, T., B. Straver, and D. van den Berg. 2002. Possibilities for using photoperiodism to program flowering of sunflowers (Helianthus annuus) in the greenhouse and in the open. Acta Hort. 580:101-109.

Dyer, J.H., J. Skok, and N.J. Scully. 1959. Photoperiod behavior of sunflower. Bot. Gaz. 121:50-55.

Goyne, P.J. and A.A. Schneiter. 1988. Temperature and photoperiod interactions with the phenological development of sunflower. Agron. J. 80:777-784.

Hayata, Y. and Y. Imaizumi. 2000. Effect of photoperiod on flower bud development of ornamental sunflowers (Helianthus annums L.). J. Jpn. Soc. Hort. Sci. 69:708-710.

Marc, J. and J.H. Palmer. 1981. Photoperiodic sensitivity of inflorescence initiation and development in sunflower. Field Crops Res. 3:155-164.

Mattson, N.S. and J.E. Erwin. 2005. The impact of photoperiod and irradiance on flowering of several herbaceous ornamentals. Sci. Hort. 104:275-292.

Rawson, H.M. and J.H. Hindmarsh. 1982. Effects of temperature on leaf expansion in sunflower. Austral. J. Plant Physiol. 9:209-219.

Schuster, W. and R. Boyce. 1971. Der Einfluss von Temperatur und Tageslaenge auf verschiedene Sonnenblumensorten unter kontrollierten Klimabedingungen und im Freiland. Zeitschrift fuer Pflanzenzuechtung 65:151-176.

Yanez, P., H. Ohno, and K. Ohkawa. 2005. Photoperiodic response and vase life of ornamental sunflower cultivars. HortTechnology 15:386-390.

Yanez, P., S. Chinone, R. Hirohata, H. Ohno, and K. Ohkawa. 2012. Effects of time and duration of short-day treatments under long-day conditions on flowering of a quantitative short-day sunflower (Helianthus annuus L.) 'Sunrich Orange' Sci. Hort. 140:8-12. 